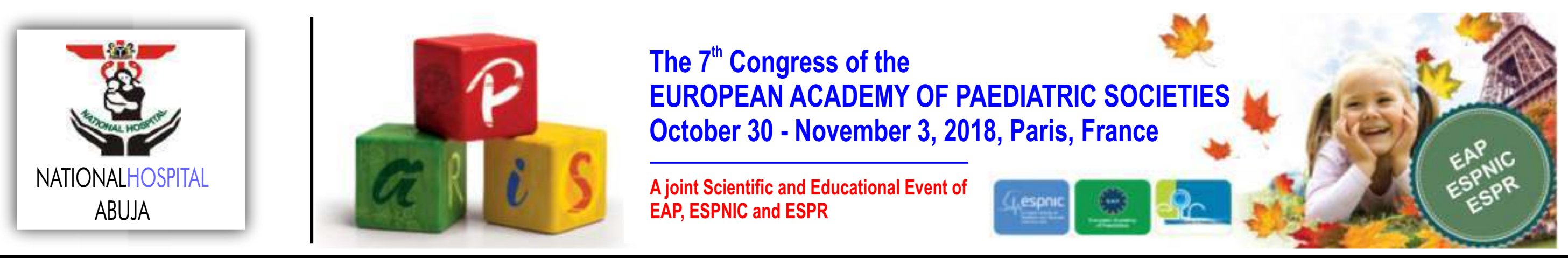

\title{
PATTERN OF RENAL FUNCTION AND IMPACT OF ROUTINE MEDICATIONS ON RENAL FUNCTION OF HIV INFECTED CHILDREN IN A TERTIARY HOSPITAL IN SUB-SAHARAN AFRICA \\ Ezeh GO ${ }^{1}$, Oniyangi $\mathrm{O}^{1}$, Babaniyi IB ${ }^{1}$, Nwatah VE ${ }^{1 *}$, Eke FU ${ }^{2}$ \\ National Hospital Abuja, Nigeria, ${ }^{2}$ University of Port Harcourt Teaching Hospital, Nigeria \\ * Corresponding author: Nwatah VE; Department of Paediatrics, \\ National Hospital Abuja, Plot 132 Central Business District, Garki Abuja, Nigeria; nwatven@yahoo.com
}

\section{BACKGROUND}

HIV infection is now pandemic in humans. Globally, women account for half of HIV infection and 3.3 million children live with the virus. ${ }^{1}$ Sub-Saharan Africa is the worst hit by the epidemic with 1.8 million new HIV infections, out of which there were 270,000 children under $15 y$ ars in $2011^{2}$ In Nigeria, a study of renal function in HIV infected children using Cystatin C to estimate glomerular filtration rate (GFR) reported a prevalence of chronic kidney disease of $13.3 \%{ }^{4}$

Kidney diseases in HIV infected children have strong association with chronic kidney disease (CKD) and progression to end stage renal failure..$^{9-12}$ The variations in abnormal renal function in HIV infected children reported from country to country may be due to different renal parameters studied, scanty report of renal diseases in some regions, and availability of diagnostic facilities. ${ }^{18}$

We aim to determine the pattern of renal abnormalities seen in HIV infected children. We also intend to determine associations between eGFR and CD4+ count, and WHO clinical staging of HIV disease in HIV infected children as well as to determine the relationship(s) between eGFR and use of HAART, and other drugs for treatment of opportunistic infections (OIs) and their duration of use in HIV infected children seen at the National Hospital Abuja.

\section{METHODS AND MATERIALS}

Study design and study location

This is a descriptive, prospective and cross sectional study of children with HIV infection seen at the National Hospital Abuja in the Federal Capital Territory (FCT), Nigeria.

All the HIV infected children in the age range of 6 months to 15 years, who met the inclusion criteria were consecutively recruited as they presented in the Clinic/Paediatric-ward during the study period of 6 months.

\section{Data collection and Data analysis}

A questionnaire was used to obtain subjects information such as name, age, gender, tribe, address, religion (demographic characteristics) from the patients/ parents/guardians. Each subject's CD4+ count and CD+ percentage (for children $<5$ years) was determined and their immunological classification assessed by WHO immunological classification

For simple proportions, frequency tables were generated for description of age, gender, clinical staging and mean eGFR. The level of statistical significance was set at $p$ less than 0.05 . Data analysis was done using the Statistical Package for Social Sciences (SPSS) version 17.

\section{RESULTS}

The age range of the study subjects was 12 months to 15 years with the mean age (SD) of 8.21years (3.61). There were $129(58.4 \%)$ male and $92(41.6 \%)$ female children with male to female ratio 1:0.7. The mean age (SD) for males was 7.87years (3.49) while that for females was 8.70years (3.71). The role(s) of laboratory/ interventional parameters such as mean CD4 + count, WHO clinical staging of HIV infection, use of HAART rifampicin and cotrimoxazole beyond 6 months and HIV associated immunodeficiency in development of CKD where not statistically significant except in those with severe HIV immunological classification (Table 2). The relationship between eGFR and CD4 of participants < 5 yrs as well as those $5 y$ rs and above were not statisticall. significant

Table 1: Drug use among 221 HIV infected children

\begin{tabular}{|c|c|c|c|}
\hline \multicolumn{2}{|l|}{ Characteristics } & $\begin{array}{c}\text { Number } \\
\text { (N) }\end{array}$ & $\begin{array}{c}\text { Percentage } \\
(\%)\end{array}$ \\
\hline \multicolumn{4}{|l|}{ ARV Combination use } \\
\hline \multicolumn{2}{|l|}{$\mathrm{ZDV}+3 \mathrm{3TC}+\mathrm{NVP}$} & 131 & 60.6 \\
\hline \multirow{2}{*}{\multicolumn{2}{|c|}{$\begin{array}{l}\mathrm{ZDV}+3 \mathrm{TC}+\mathrm{EFV} \\
\mathrm{ZDV}+3 \mathrm{TC}+\mathrm{LP} / \mathrm{r}\end{array}$}} & 64 & 29.6 \\
\hline \multirow{2}{*}{\multicolumn{2}{|c|}{$A B C+L P / r+D D I$}} & 9 & 4.2 \\
\hline & & 4 & 1.8 \\
\hline \multicolumn{2}{|l|}{$3 T C+A B C+L P / r$} & 3 & 1.4 \\
\hline \multicolumn{2}{|l|}{$A B C+L P / r+T D F$} & 3 & 1.4 \\
\hline \multirow{2}{*}{\multicolumn{2}{|c|}{$\mathrm{ZDV}+3 \mathrm{TC}+\mathrm{ABC}$}} & 1 & 0.5 \\
\hline & & 1 & 0.5 \\
\hline \multirow{3}{*}{ ARV use (HAART) } & Drug naïve & 5 & 2.3 \\
\hline & $<6$ months & 11 & 5.0 \\
\hline & $>6$ months & 205 & 92.7 \\
\hline \multirow{3}{*}{ Rifampicin use } & Drug naive & 163 & 73.8 \\
\hline & $<6$ months & 25 & 11.3 \\
\hline & $>6$ months & 33 & 14.9 \\
\hline \multirow{3}{*}{ Cotrimoxazole use } & Drug naive & 53 & 24.0 \\
\hline & $<6$ months & 26 & 11.8 \\
\hline & $>6$ months & 142 & 64.0 \\
\hline \multirow{3}{*}{ Nephrotoxic drug use } & Ise Rifampicin & 58 & 92.0 \\
\hline & Tenofovir (TDF) & 3 & 4.8 \\
\hline & Acyclovir & 2 & 3.2 \\
\hline
\end{tabular}

Table 2: Laboratory/ interventional characteristics in children with CKD as against those with eGFR of $\geq 60 \mathrm{ml} / \mathrm{min} / 1.73 \mathrm{~m}^{2}$

\begin{tabular}{lcccc}
\hline Parameters & $\begin{array}{c}\text { Children } \\
\text { with CKD } \\
\mathbf{n = 5}\end{array}$ & $\begin{array}{c}\text { Children } \\
\text { Without CKD } \\
\mathbf{n = 2 1 6}\end{array}$ & $\begin{array}{c}\text { Chi } \\
\text { Square } \\
\mathbf{x}^{\mathbf{2}}\end{array}$ & P value \\
\hline Mean CD4 + Count (cells/mI) & 1012 & 897.67 & 75.777 & 0.437 \\
HIV clinical Stage IV & 1 & 15 & 3.707 & 0.295 \\
HIV clinical Stage III & 1 & 69 & 3.707 & 0.295 \\
$\begin{array}{l}\text { Use of HAART } \\
\text { beyond 6 months }\end{array}$ & 4 & 201 & 2.353 & 0.232 \\
$\begin{array}{l}\text { Use of Rifampicin } \\
\text { > } 6 \text { months }\end{array}$ & 0 & 33 & 1.343 & 0.431 \\
$\begin{array}{l}\text { Use of Cotrimoxazole } \\
\text { Severe HIV immunological }\end{array}$ & 5 & 163 & 1.614 & 0.250 \\
classification & 3 & 216 & 12.666 & 0.005 \\
\hline
\end{tabular}

Table 3: Association between severity of clinical staging of HIV infection and occurrence of chronic kidney disease

\begin{tabular}{lcccc}
\hline $\begin{array}{l}\text { WHO clinical } \\
\text { Staging }\end{array}$ & $\begin{array}{c}\text { Patients } \\
\text { With CKD } \\
\mathbf{n = 5}\end{array}$ & $\begin{array}{c}\text { Patients } \\
\text { Without CKD } \\
\mathbf{n = 2 1 6}\end{array}$ & $\begin{array}{c}\text { Chi square } \\
\mathbf{x}^{\mathbf{2}}\end{array}$ & P value \\
\hline Asymptomatic & 2 & 35 & 3.707 & 0.295 \\
Mild & 1 & 97 & 3.707 & 0.295 \\
Advanced & 1 & 69 & 3.707 & 0.295 \\
Severe & 1 & 15 & 3.707 & 0.295 \\
\hline
\end{tabular}

Table 4: Association between eGFR and WHO immunological classification of subjects with HIVIAIDS

\begin{tabular}{lcccl}
\hline $\begin{array}{l}\text { Classification of } \\
\text { HIV- associated } \\
\text { immunodeficiency }\end{array}$ & $\begin{array}{c}\text { eGFR stages }\left(\mathrm{ml} / \mathrm{min} / \mathbf{1 . 7 3 \mathrm { m } ^ { 2 } )}\right. \\
\text { (stage I) }\end{array}$ & $\begin{array}{c}60-89 \\
\text { (stage II) }\end{array}$ & $\begin{array}{c}\text { Total }(\%) \\
\text { (stage III) }\end{array}$ & \\
\hline None or not significant & 140 & 2 & 1 & $143(64.7 \%)$ \\
Mild & 21 & 0 & 0 & $21(9.5 \%)$ \\
Advanced & 29 & 1 & 1 & $31(14.0 \%)$ \\
Severe & 21 & 2 & 3 & $26(11.8 \%)$ \\
Total & 211 & 5 & 5 & $221(100.0 \%)$ \\
\hline
\end{tabular}

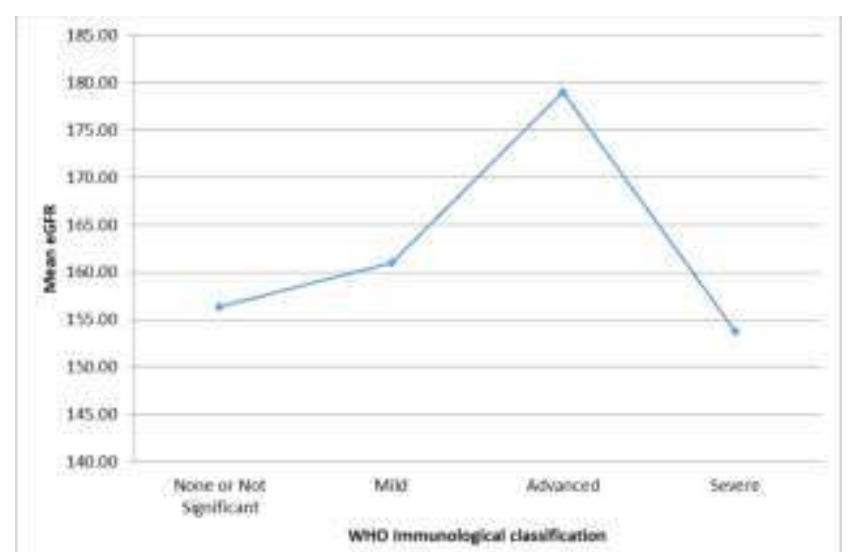

Figure 1: The distribution of mean GFR among the HIV-associated immunodeficiency stages is represented in the graph

\section{DISCUSSION}

Four (80\%) of the HIV infected children with CKD had advanced/severe immunosuppression while one had mild immunosuppression. The findings showed the significant association between chronic kidney disease and advanced/severe immunosuppression. This is in keeping with findings of previous studies that low CD $4 \%$, counts were associated with both opportunistic infection and diseases, ${ }^{20-22}$ though not specific for kidney disease alone. Children with mild immunosuppression and CKD could have had pre-existing undetected renal disease; HIV related kidney disease by the virus itself as the kidney serves as a reservoir of infection; ${ }^{9,23,24}$ o from other causes of CKD

Clinically, none of the children presented with symptoms of renal disease, though some (2.3\%) were detected Che have chronic kidney disease. This underscores the importance of rouline screening for renal diseases. Similarly, the mismatch between clinical staging and development of renal disease makes it imperative for clinicians to screen all HIV infected children, irrespective of clinical staging for possible ongoing renal damage.

This study found a significant association between severity of HIV-associated immunological stages and CKD among HIV infected children. The more severe the immune deficiency state, the greater the likelihood of worsening renal function. Emem et $\mathrm{al}^{18}$ and other authors ${ }^{31,32}$ reported worsening kidney function in advanced severe immunological stages of HIV disease as compared to stages with less immunosuppression. The steep rise and decline of eGFR in the advanced and severe immunological stages could be related to initial deterioration of kidney function, subsequent hyper-filtration and kidney damage respectively.

The subjects that used rifampicin for less than 6 months had higher mean eGFR than those that used it for longer than 6 months, although this difference was not statistically significant. This observation is in agreement with reports from studies ${ }^{35,36,37,38,39}$ that noted prolonged use of rifampicin as a cause of deterioration of renal function.

\section{CONCLUSION AND RECOMMENDATIONS}

The impact of routine medications used on renal status of HIV infected children was not significant. Majority of the HIV infected children did not have CKD. It is imperative to regularly assess renal function of those with advanced WHO immunological classification.

\section{Conflict of interest: None}

Funding: None

Acknowledgement: We wish to thank all the patients and patients' caregivers for the cooperation as well as all the healthcare professionals who contributed in the patients' management.

\section{REFERENCES}

1. UNAIDS (2012). Global Fact Sheet 2012: World AIDS Day 2012

UNAIDS (2012) Region Fact Shet2012: Sub-Saharan Africa Nov 2012

Strauss J, Abitbol CL, Zilleruelo G, Scott G, Paredes A, Malaga S et al. Renal disease in children with the acquired immunodeficiency syndrome. N Engl J Med. 1989; 321:625-630.

Kidney function of HIV infected children in ; $13: 17-25$. Fransisco

Gwendolyn BS. Renal Diseases in Adolescents with Human Immunodeficiency Virus. 20th Annual HIV Conf of the Florida/ Carribean. May 13-14,2011.

7. Fishman JA. BK virus nephropathy - polyomavirus adding insult to injury. N Engl J Med. 2002; 347:527 - 530. de Silva TI, Post FA, Graffin MD, Dockrel DH. HIV-1 infection and the kidney: an evolving challenge in HIV medicine. Mayo Clin Proc. 2007; 82: 1103-1116.

Lederman MM, Rodriguez B, Seig S. Inmunopathogenesis of HIV infection. HIV In Site Knowledge Base Chapter. Oct. 2004. Reviewed Jan. 2006. [on line ] [cited 2011Jul 15] [12 screens]. Available from: URL:

10. Ross MJ, Klotman PE. HIV associated nephropathy: a disease of ethnic disparity. AIDS. 2004; 18:1089-1099. 